
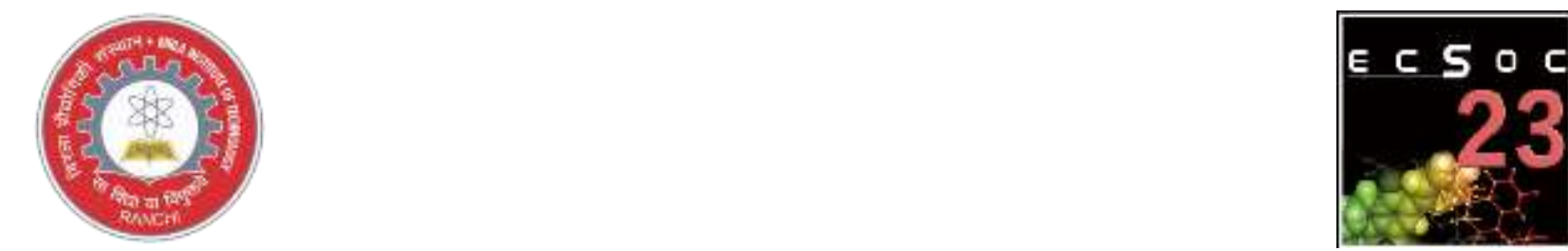

\title{
BIOACTIVE GRAFT CO-POLYMER FOR THE TREATMENT OF BREAST CANCER
}

\author{
Rojalini Samanta, Harish Kumar Singh, Manik Ghosh* \\ Birla Institute of Technology, Mesra, Ranchi, Jharkhand (835215), INDIA \\ *Corresponding Author's E-mail: manik@bitmesra.ac.in
}

\begin{abstract}
Cancer is one of the most researched areas nowadays due to the increasing incidences of cancer patients and unavailability of cheap and highly efficient drugs. Cancer is the uncontrolled proliferation of the body's own cell. The cancer cells are dedifferentiated and lose their normal function. Cancer may be of two types metastatic and benign, out of which metastatic cancer is serious form. We are aware of the fact that the cancer cells differ from normal cells in many aspects. One such aspect is $\mathrm{pH}$ of cancer cells. The cancer cell has a $\mathrm{pH}$ lower than that of the normal cells of the body. In this research, we have prepared target-specific and pH-sensitive bioactive polymer using a combination of different natural polymer like polyvinyl alcohol, sodium alginate in a different ratio. Since, these polymers are $\mathrm{pH}$ sensitive, they will release the loaded drug only at the cancer site thus reducing the various side effects of the drug and drug toxicity.
\end{abstract}

Keywords: Breast cancer; anticancer; bioactive polymers; $\mathrm{pH}$ sensitive polymer

\section{INTRODUCTION}

Cancer is a multi-step process in which cells undergoes metabolic and behavioral changes, leading them to proliferate in an excessive and untimely way. These changes arise through modifications in mechanisms that control cell proliferation and lifespan, relationships with neighboring cells, and capacity to escape the immune system. Modifications that lead to cancer include genetic changes that modify the DNA sequence. Another way to change the programme of cells is to modify the conformation of chromatin, the structure that wraps up DNA and regulates its access by DNA reading, copying and repair machineries. Such changes are called "epigenetic". 

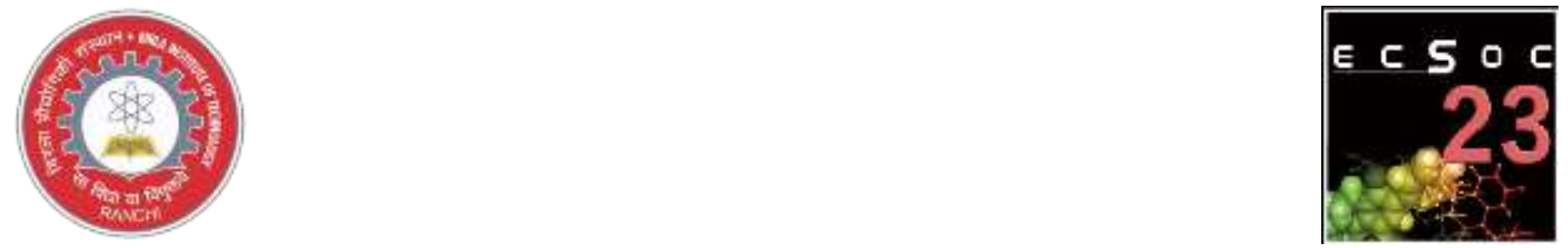

Carcinogens like ionising radiation (X Rays, UV light), chemicals - tar from cigarettes and virus infection - papilloma virus can be responsible for cervical cancer. Hereditary predisposition Some families are more susceptible to getting certain cancers. Breast cancer is always caused by a genetic abnormality (a "mistake" in the genetic material). However, only 5-10\% of cancers are due to an abnormality inherited from your mother or father. About $90 \%$ of breast cancers are due to genetic abnormalities that happen as a result of the aging process and the "wear and tear" of life in general.

Nowadays biological products are used to treat any disease to avoid side effects. Polymers are used as a biological product. Single-layer polymer doesn't show the desired effect, therefore, alteration with their chemical structure is done. The addition of monomer (branches) to the main linear chain (backbone) is called grafting or the obtained product is known as graft copolymer. Branched molecular structures are known as graft copolymer. The addition of monomer (side chains) are random. Amphiphilic graft copolymer, solubility plays a very important role in emulsification, solubility of monomer (side chain or graft) are different from the main linear chain (backbone). The addition of graft on the polymeric chain is considered as chemical modification. In reference to the branched structure of graft copolymer, graft and backbone are of the same chemical nature. The application of comb-like polymers are the methods which are used in graft copolymer. The name graft should be given after the name of backbone polymer according to international nomenclature rule. The word graft indicates the structure of the molecules. Thus poly(styrenegraft-isoprene) means that a polystyrene backbone carries polyisoprene grafts; poly[styrene-graft(styrene-co-isoprene)] indicates that the grafts are themselves a random copolymer of styrene and isoprene. Sometimes is difficult to understand which polymer is the backbone and which constituents the graft, therefore, nomenclature is not always obeyed. The fraction of monomer units of the backbone which carry a graft is called grafting degree, this term is commonly used in grafting technique.

\section{METHODS}

OBJECTIVE OF THE EXPERIMENT: To synthesize and characterize some graft copolymers. 


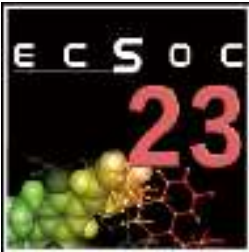

\section{METHODOLOGY:}

The method utilized for preparing the graft co-polymer is microwave irradiation method.

\section{Method of preparation of Sample 1:}

1. The sample 1 was prepared by taking two polymers, sodium alginate, and gelatin in the ratio $1: 1$.

2. $150 \mathrm{mg}$ each of both these polymers was weighed and added in small amounts to a beaker containing distilled water just enough to dissolve the polymer, a magnetic bead was placed into it and it was then kept on a magnetic stirrer maintained at a particular temperature.

3. $100 \mathrm{mg}$ of acrylamide was added slowly in small amounts followed by the addition of 25 mg of ammonium persulphate (APS) slowly to the beaker.

4. The beaker was then placed in an ice bath for 1 minute and again in the microwave for 1 minute at a power of $300 \mathrm{w}$.

5. This cycle was repeated until the graft copolymer was formed.

6. The graft copolymer formed was precipitated using acetone and then it was filtered.

\section{Method of preparation of Sample 2:}

1. Two polymers, PVA (Polyvinyl alcohol) and sodium alginate were taken in the ratio of $1: 1$.

2. $150 \mathrm{mg}$ of each of these polymers were added slowly in small amounts in a beaker containing distilled water just enough to dissolve the polymer andwas then placed on a magnetic stirrer along with a magnetic bead maintained at a particular temperature.

3. $100 \mathrm{mg}$ of acrylamide was added slowly in small amounts followed by the addition of 25 mg of ammonium persulphate (APS) slowly to the beaker.

4. The beaker was then placed in an ice bath for 1 minute and again in the microwave for 1 minute at a power of $300 \mathrm{w}$.

5. This cycle was repeated until the graft copolymer was formed.

6. The graft copolymer formed was precipitated using acetone and then it was filtered. 

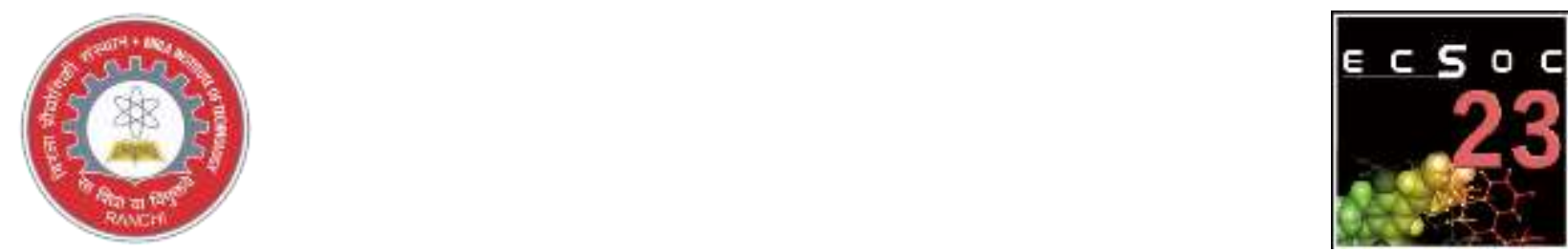

\section{Method of preparation of Sample 3}

1. Two polymers, PVA (Polyvinyl alcohol) and gelatin were taken in the ratio of 1:1.

2. $150 \mathrm{mg}$ of each of these polymers were added slowly in small amounts in a beaker containing distilled water just enough to dissolve the polymer and was then placed on a magnetic stirrer along with a magnetic bead maintained at a particular temperature.

3. $100 \mathrm{mg}$ of acrylamide was added slowly in small amounts followed by the addition of 25 mg of ammonium persulphate (APS) slowly to the beaker.

4. The beaker was then placed in an ice bath for 1 minute and again in the microwave for 1 minute at a power of $300 \mathrm{w}$.

5. This cycle was repeated until the graft copolymer was formed.

6. The graft copolymer formed was precipitated using acetone and then it was filtered.

The graft copolymers obtained were characterized using infra-red spectrophotometry and scanning electron microscopy.

\section{RESULTS AND DISCUSSION:}

\section{SCANNING ELECTRON MICROSCOPE (SEM) OBSERVATION}

The prepared samples were dried. Then size-reduction prepared samples was done in mortar and pestle. The sample was observed under interior Scanning electron microscopy (Jeol, JSM6390LV).

\section{SAMPLE 1: Sodium alginate and Gelatin}
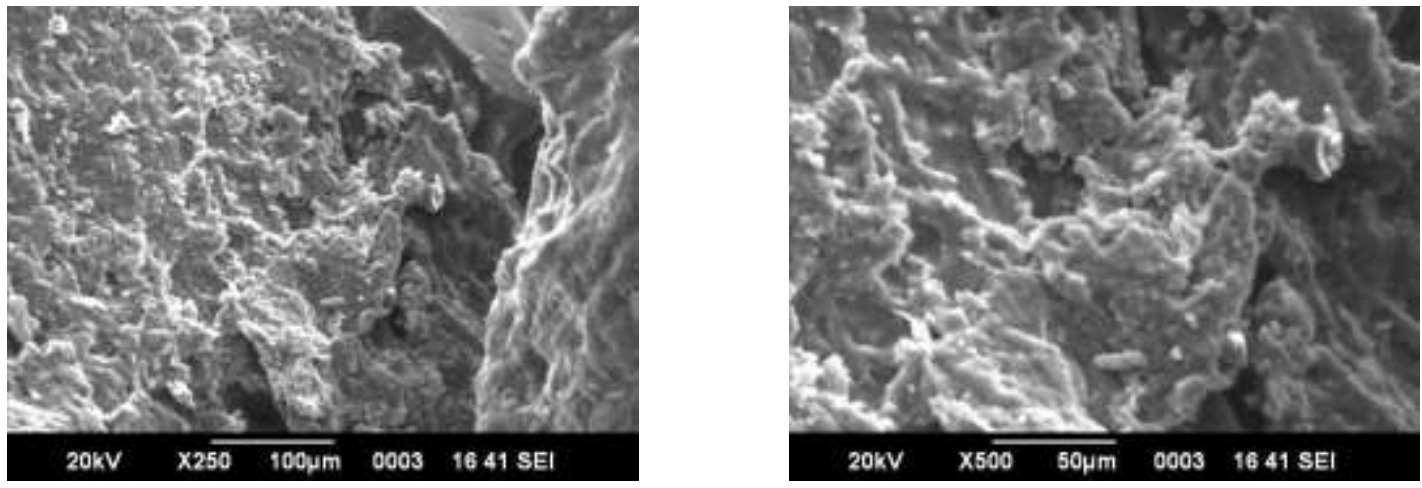

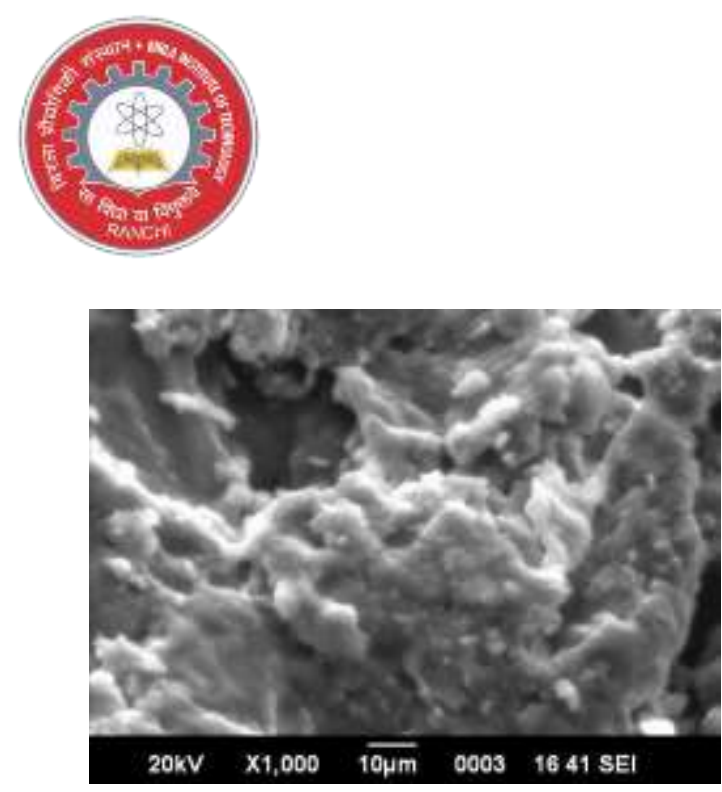

Fig 1: SEM of Sodium Alginate and Gelatin at different magnification (250X, 500X, 1000X, 2000X)

SAMPLE 2: Polyvinyl alcohol (PVA) and Sodium alginate
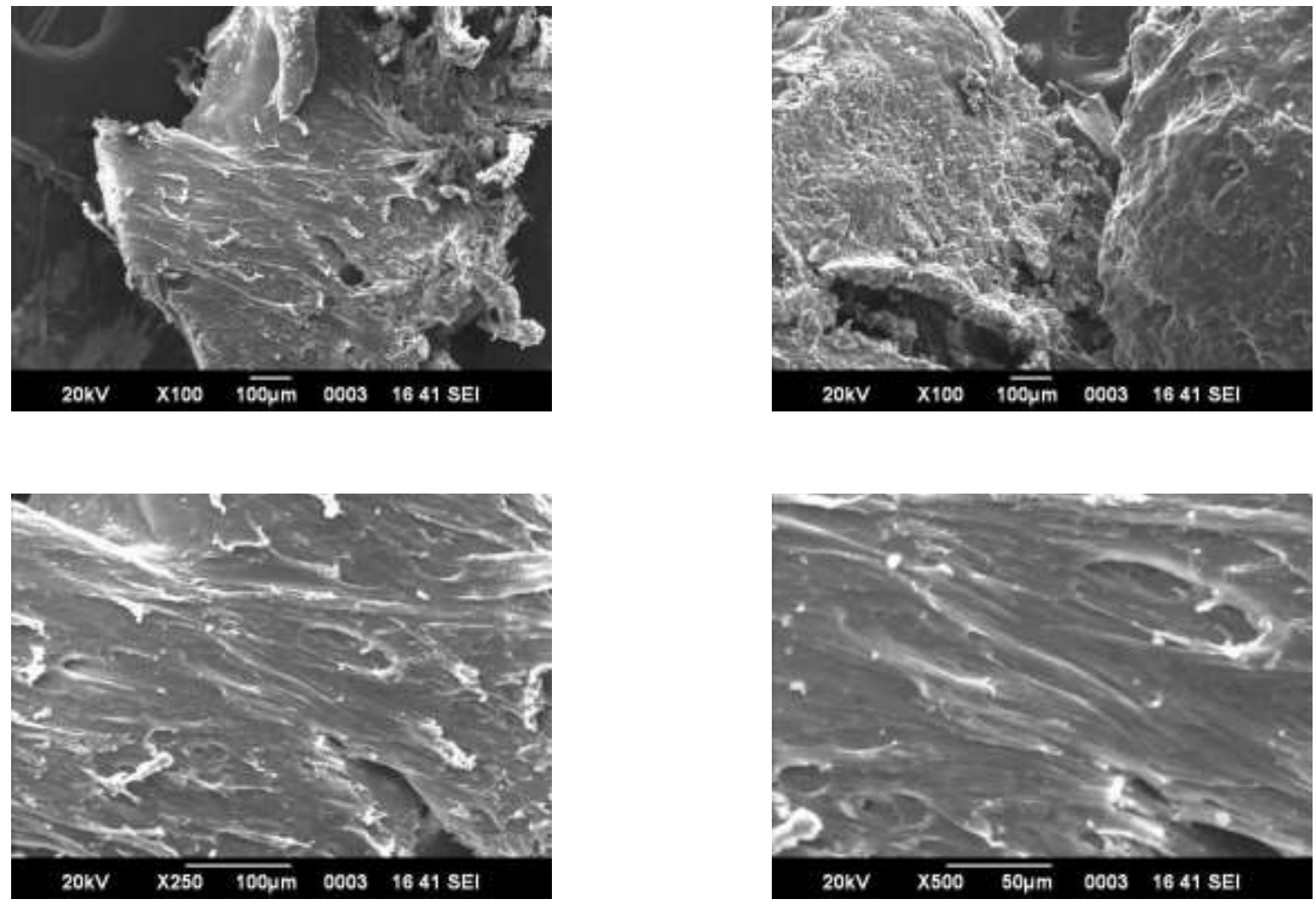

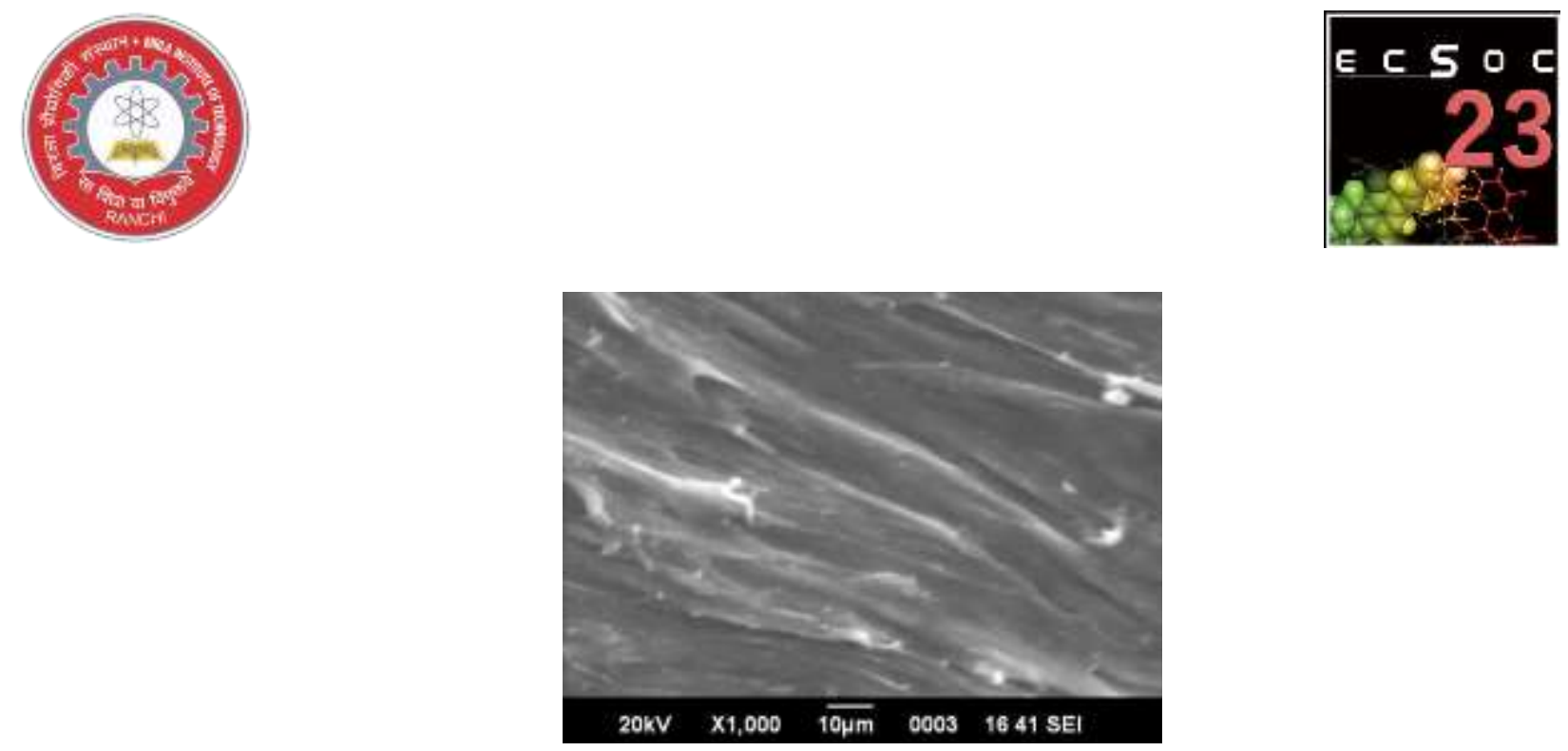

Fig 2: SEM of PVA and Sodium Alginate at different magnification(100X, 250X, 500X, 1000X).

SAMPLE 3: Polyvinyl alcohol (PVA) and Gelatin
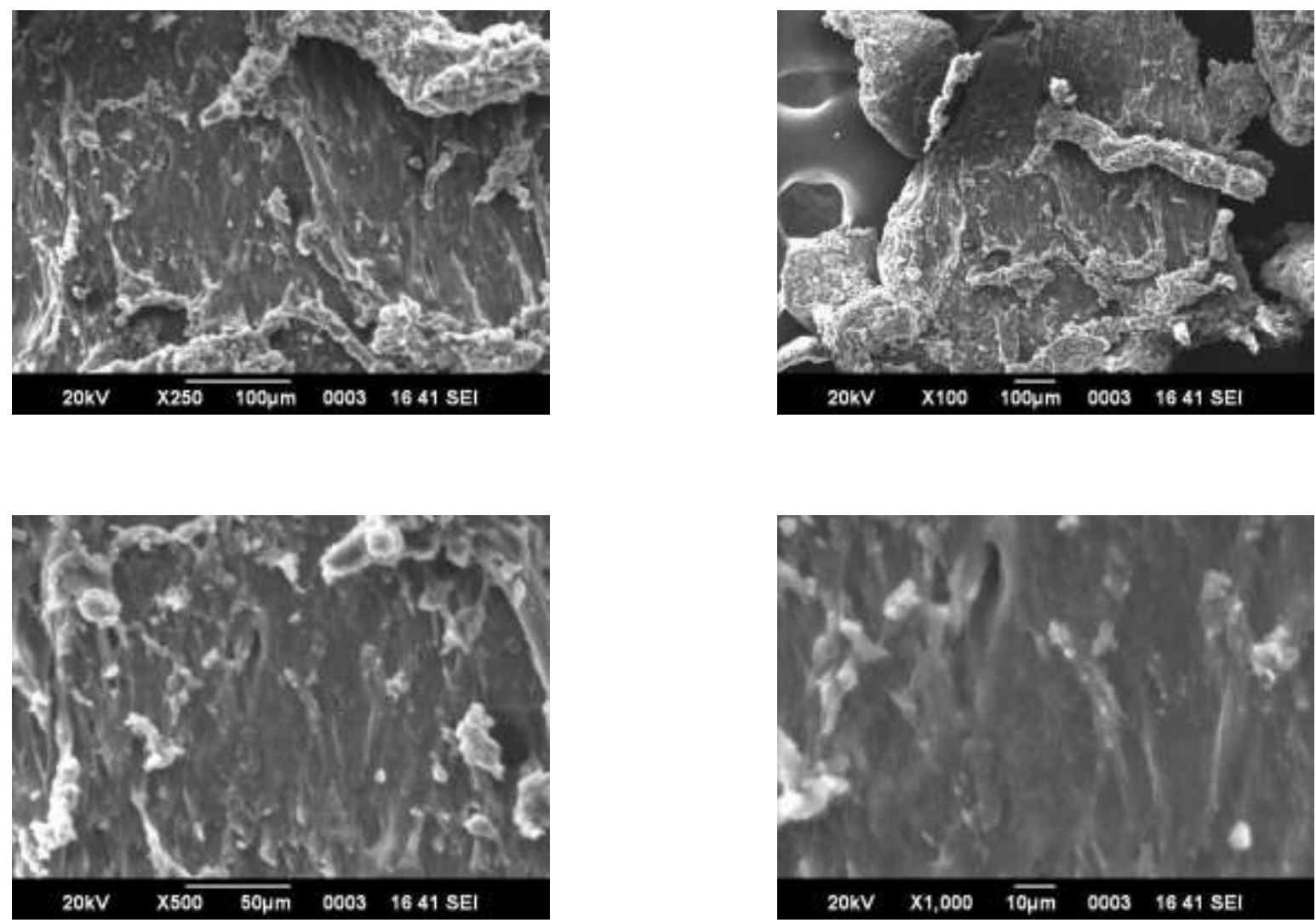


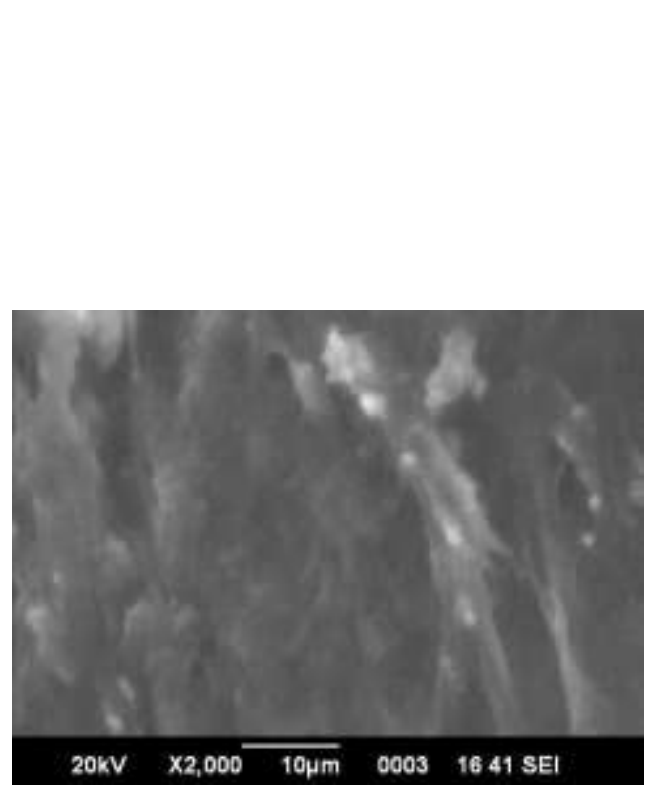

Fig 3: SEM of PVA and Gelatin at different magnification(100X, 250X, 500X, 1000X, 2000X).

\section{INFRARED SPECTROSCOPIC ANALYSIS}

SAMPLE 1: Sodium alginate and Gelatin
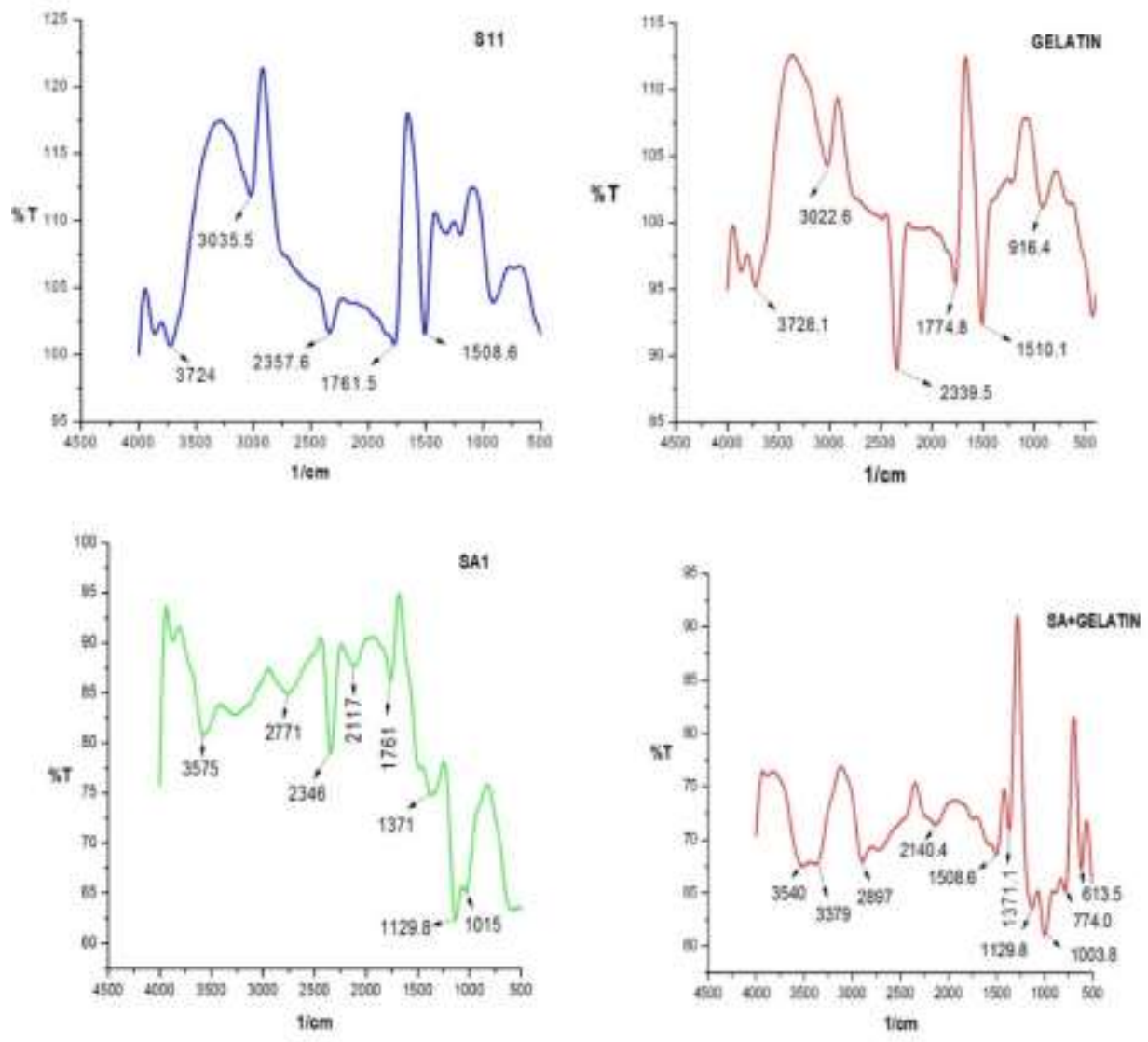

Fig 4: FTIR Spectrum of Grafted copolymer MR-I (Gelatin + Sodium alginate) - S11 
Table 1: FTIR ( IR bands and Groups)

Sodium Alginate + Gelatin - Physical Mixture

\begin{tabular}{|l|l|}
\hline IR Bands & GROUPS \\
\hline $3540 \mathrm{~cm}^{-1}$ & O-H \\
\hline $3379 \mathrm{~cm}^{-1}$ & CONH \\
\hline $2897 \mathrm{~cm}^{-1}$ & C-H \\
\hline $2140 \mathrm{~cm}^{-1}$ & $\mathrm{C} \equiv \mathrm{C}, \mathrm{C} \equiv \mathrm{N}, \mathrm{N}=\mathrm{C}=\mathrm{O}, \mathrm{N}=\mathrm{C}=\mathrm{S}, \mathrm{N}=\mathrm{C}=\mathrm{N}$ \\
\hline $1508 \mathrm{~cm}^{-1}$ & $\mathrm{C}=\mathrm{O}$ \\
\hline $1371 \mathrm{~cm}^{-1}$ & $\mathrm{C}-\mathrm{F}$ \\
\hline $1129 \mathrm{~cm}^{-1}$ & $\mathrm{C}-\mathrm{O}-\mathrm{C}$ \\
\hline $1003 \mathrm{~cm}^{-1}$ & $\mathrm{C}-\mathrm{O}-\mathrm{C}$ \\
\hline $774 \mathrm{~cm}^{-1}$ & C-CL \\
\hline $613 \mathrm{~cm}^{-1}$ & C-BR \\
\hline
\end{tabular}

S11 - Graft

\begin{tabular}{|l|l|}
\hline IR Bands & GROUPS \\
\hline $3815 \mathrm{~cm}^{-1}$ & $\mathrm{~N}-\mathrm{H}$ \\
\hline $3713 \mathrm{~cm}^{-1}$ & $\mathrm{~N}-\mathrm{H}$ \\
\hline $3024 \mathrm{~cm}^{-1}$ & $\mathrm{C}-\mathrm{H}$ \\
\hline $2335 \mathrm{~cm}^{-1}$ & $\mathrm{C} \equiv \mathrm{C}, \mathrm{C} \equiv \mathrm{N}, \mathrm{N}=\mathrm{C}=\mathrm{O}, \mathrm{N}=\mathrm{C}=\mathrm{S}, \mathrm{N}=\mathrm{C}=\mathrm{N}$ \\
\hline $1761 \mathrm{~cm}^{-1}$ & $\mathrm{C}=\mathrm{O}$ \\
\hline $1508 \mathrm{~cm}^{-1}$ & $\mathrm{C}=\mathrm{O}$ \\
\hline
\end{tabular}

\section{INTERPRETATION:}

- The presence of a sharp peak at the wavelength of $3724 \mathrm{~cm}^{-1}$ may be due to N-H present in gelatin.

- The presence of a sharp peak at the wavelength of $3035 \mathrm{~cm}^{-1}$ may be due to $\mathrm{C}-\mathrm{H}$ present in gelatin.

- The presence of a sharp peak at the wavelength of $2357 \mathrm{~cm}^{-1}$ may be due to $\mathrm{C} \equiv \mathrm{N}$ or $\mathrm{C} \equiv \mathrm{C}$ or $\mathrm{N}=\mathrm{C}=\mathrm{S}$ or $\mathrm{N}=\mathrm{C}=\mathrm{N}$ groups present in both gelatin and sodium alginate.

- The presence of a sharp peak at the wavelength of $1761 \mathrm{~cm}^{-1}$ may be due to the $\mathrm{C}=\mathrm{O}$ group present in both gelatin and sodium alginate.

- The presence of a sharp peak at the wavelength of $1508 \mathrm{~cm}^{-1}$ may be due to the $\mathrm{C}=\mathrm{O}$ group present in gelatin. 


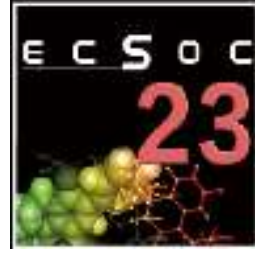

SAMPLE 2: Polyvinyl alcohol (PVA) and Sodium alginate
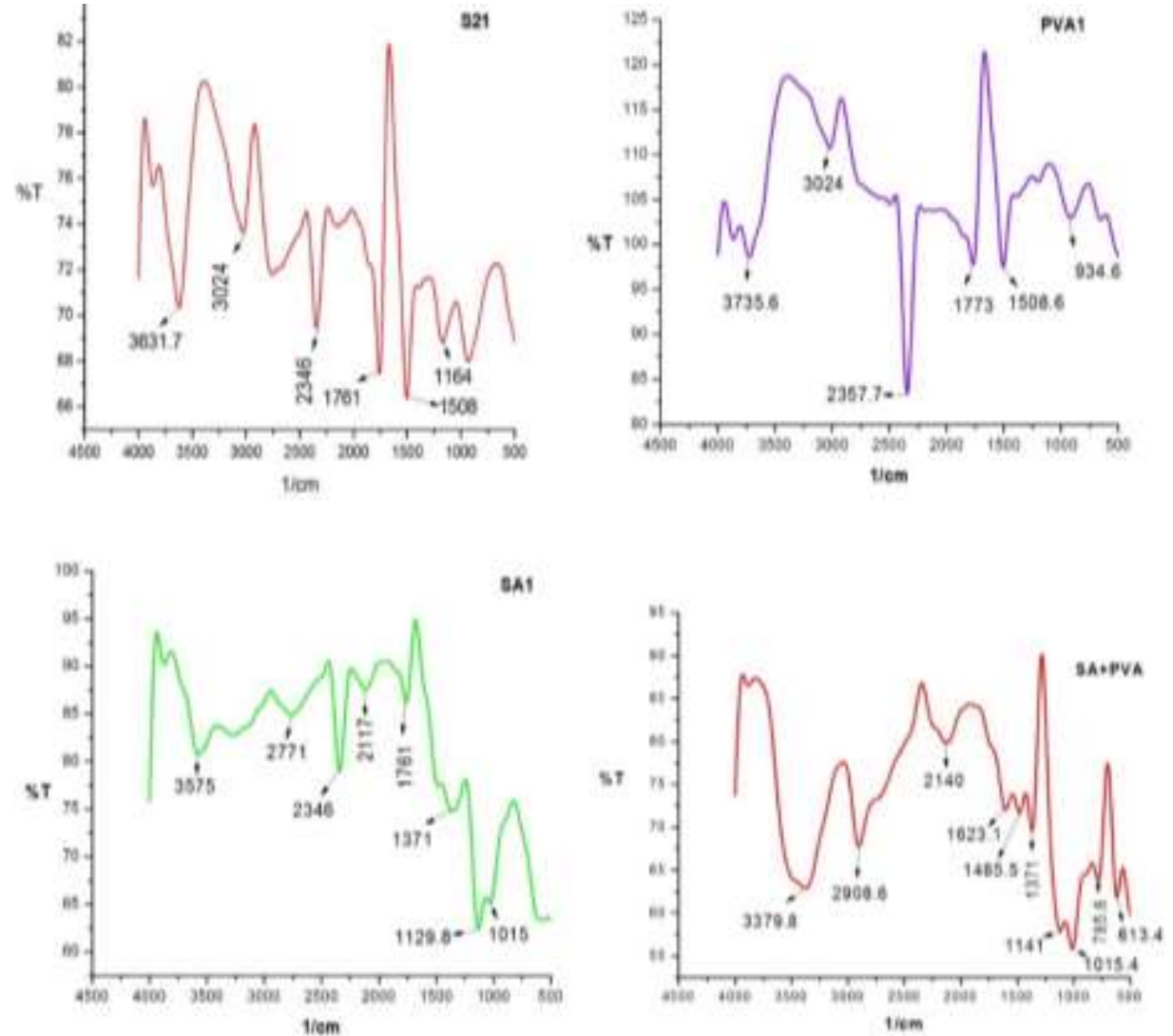

Fig 5: FTIR Spectrum of Grafted co-polymer MR-II (Sodium alginate + Polyvinyl chloride) $-\mathbf{S 2 1}$

Table 2: FTIR ( IR bands and Groups)

PVA (Polyvinyl alcohol) + Sodium Alginate - Physical Mixture

\begin{tabular}{|l|l|}
\hline IR Bands & GROUPS \\
\hline $3379 \mathrm{~cm}^{-1}$ & CONH \\
\hline $2908 \mathrm{~cm}^{-1}$ & $\mathrm{C}-\mathrm{H}$ \\
\hline $2140 \mathrm{~cm}^{-1}$ & $\mathrm{C} \equiv \mathrm{C}, \mathrm{C} \equiv \mathrm{N}, \mathrm{N}=\mathrm{C}=\mathrm{O}, \mathrm{N}=\mathrm{C}=\mathrm{S}, \mathrm{N}=\mathrm{C}=\mathrm{N}$ \\
\hline $1623 \mathrm{~cm}^{-1}$ & $\mathrm{C}=\mathrm{O}$ \\
\hline $1374 \mathrm{~cm}^{-1}$ & $\mathrm{C}-\mathrm{F}$ \\
\hline $1141 \mathrm{~cm}^{-1}$ & $\mathrm{C}-\mathrm{O}-\mathrm{C}$ \\
\hline $1015 \mathrm{~cm}^{-1}$ & $\mathrm{C}-\mathrm{O}-\mathrm{C}$ \\
\hline $785 \mathrm{~cm}^{-1}$ & $\mathrm{C}-\mathrm{CL}$ \\
\hline $613 \mathrm{~cm}^{-1}$ & C-BR \\
\hline
\end{tabular}


S21 - Graft

\begin{tabular}{|l|l|}
\hline IR Bands & GROUPS \\
\hline $3575 \mathrm{~cm}^{-1}$ & $\mathrm{O}-\mathrm{H}$ \\
\hline $2771 \mathrm{~cm}^{-1}$ & $\mathrm{C}=\mathrm{C}$ \\
\hline $2346 \mathrm{~cm}^{-1}$ & $\mathrm{C}-\mathrm{C}$ \\
\hline $2117 \mathrm{~cm}^{-1}$ & $\mathrm{C}=\mathrm{C}, \mathrm{C} \equiv \mathrm{N}, \mathrm{N}=\mathrm{C}=\mathrm{O}, \mathrm{N}=\mathrm{C}=\mathrm{S}, \mathrm{N}=\mathrm{C}=\mathrm{N}$ \\
\hline $1761 \mathrm{~cm}^{-1}$ & $\mathrm{C}=\mathrm{O}$ \\
\hline $1371 \mathrm{~cm}^{-1}$ & $\mathrm{C}-\mathrm{F}$ \\
\hline $1129 \mathrm{~cm}^{-1}$ & $\mathrm{C}-\mathrm{O}-\mathrm{C}$ \\
\hline $1015 \mathrm{~cm}^{-1}$ & $\mathrm{C}-\mathrm{O}-\mathrm{C}$ \\
\hline
\end{tabular}

\section{INTERPRETATION:}

- The presence of a sharp peak at the wavelength of $3575 \mathrm{~cm}^{-1}$ may be due to the $-\mathrm{OH}$ group present in sodium alginate.

- The presence of a sharp peak at the wavelength $2117 \mathrm{~cm}^{-1}$ may be due to $\mathrm{C} \equiv \mathrm{C}$ or $\mathrm{C} \equiv \mathrm{N}$ or $\mathrm{N}=\mathrm{C}=\mathrm{O}$ or $\mathrm{N}=\mathrm{C}=\mathrm{S}$ or $\mathrm{N}=\mathrm{C}=\mathrm{N}$ groups present in sodium alginate.

- The presence of a sharp peak at the wavelength $1761 \mathrm{~cm}^{-1}$ may be due to the $\mathrm{C}=\mathrm{O}$ group present in both PVA and sodium alginate.

- The presence of a sharp peak at the wavelength of $1371 \mathrm{~cm}^{-1}$ may be due to C$\mathrm{X}(\mathrm{X}=$ halogen $)$ group present in both sodium alginate and PVA.

- The presence of a sharp peak at the wavelength $1129.8 \mathrm{~cm}^{-1}$ may be due to -C-O-C-group (ether) present in sodium alginate.

- The presence of a sharp peak at the wavelength of $1015 \mathrm{~cm}^{-1}$ may be due to -C-O-C- group present in sodium alginate.

- Peaks were also obtained at wavelengths $2771 \mathrm{~cm}^{-1}$ and $2346 \mathrm{~cm}^{-1}$ 


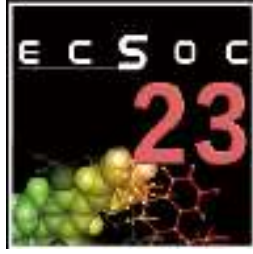

SAMPLE 3: Polyvinyl alcohol (PVA) and Gelatin
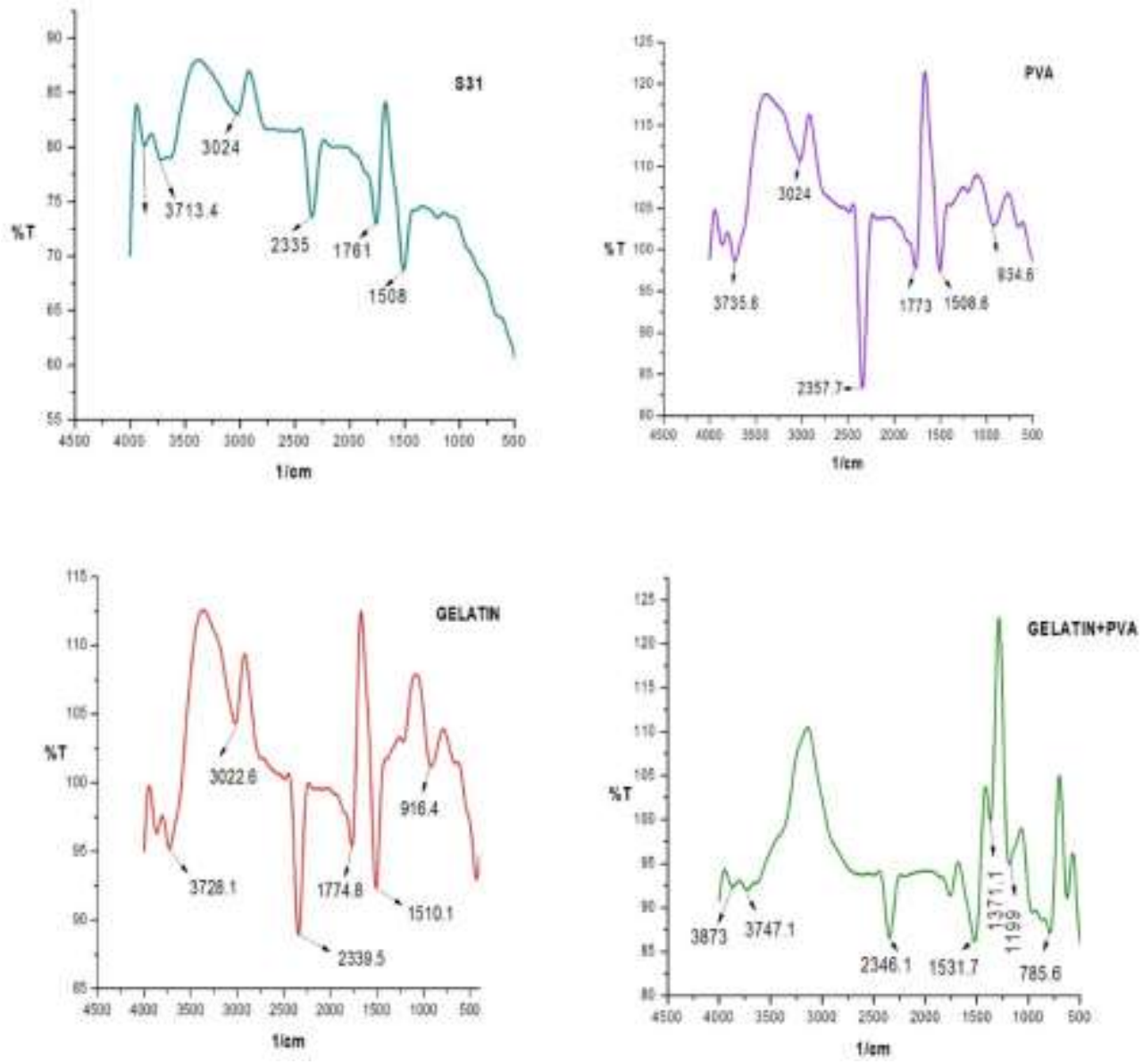

Fig 6: FTIR Spectrum of Grafted co-polymer MR-III (Gelatin + Polyvinyl chloride) - S31

Table 3: FTIR ( IR bands and Groups)

PVA (Polyvinyl alcohol) + Gelatin- Physical Mixture

\begin{tabular}{|l|l|}
\hline IR Bands & GROUPS \\
\hline $3873 \mathrm{~cm}^{-1}$ & N-H \\
\hline $3747 \mathrm{~cm}^{-1}$ & N-H \\
\hline $2346 \mathrm{~cm}^{-1}$ & $\mathrm{C}=\mathrm{C}$ \\
\hline $1531 \mathrm{~cm}^{-1}$ & $\mathrm{C}=\mathrm{O}$ \\
\hline $1371 \mathrm{~cm}^{-1}$ & $\mathrm{C}-\mathrm{F}$ \\
\hline $1189 \mathrm{~cm}^{-1}$ & $\mathrm{C}-\mathrm{O}-\mathrm{C}$ \\
\hline $785 \mathrm{~cm}^{-1}$ & $\mathrm{C}-\mathrm{CL}$ \\
\hline
\end{tabular}


S31 - Graft

\begin{tabular}{|l|l|}
\hline IR Bands & GROUPS \\
\hline $3815 \mathrm{~cm}^{-1}$ & $\mathrm{~N}-\mathrm{H}$ \\
\hline $3713 \mathrm{~cm}^{-1}$ & $\mathrm{~N}-\mathrm{H}$ \\
\hline $3024 \mathrm{~cm}^{-1}$ & $\mathrm{C}-\mathrm{H}$ \\
\hline $2335 \mathrm{~cm}^{-1}$ & $\mathrm{C}=\mathrm{C}$ \\
\hline $1761 \mathrm{~cm}^{-1}$ & $\mathrm{C}=\mathrm{O}$ \\
\hline $1508 \mathrm{~cm}^{-1}$ & $\mathrm{C}=\mathrm{O}$ \\
\hline
\end{tabular}

\section{INTERPRETATION:}

- The presence of a sharp peak at the wavelength $3815 \mathrm{~cm}^{-1}$ may be due to the N-H group present in PVA.

- The presence of a sharp peak at the wavelength $3713 \mathrm{~cm}^{-1}$ may be due to the $\mathrm{N}-\mathrm{H}$ group present in gelatin.

- The presence of a sharp peak at the wavelength $3024 \mathrm{~cm}^{-1}$ may be due to $\mathrm{C}-\mathrm{H}$ present in both gelatin and PVA.

- The presence of a sharp peak at the wavelength $1761 \mathrm{~cm}^{-1}$ may be due to $\mathrm{C}=\mathrm{O}$ present in both gelatin and PVA.

- The presence of a sharp peak at the wavelength of $1508 \mathrm{~cm}^{-1}$ may be due to $\mathrm{C}=\mathrm{O}$ present in both gelatin and PVA.

- Sharp peak was also seen at the wavelength of $2335 \mathrm{~cm}^{-1}$.

\section{Testing the swelling index of different polymers}

\section{Preparation of buffer solution:}

- For preparation of $0.2 \mathrm{M} \mathrm{KH}_{2} \mathrm{PO}_{4}, 13.609 \mathrm{gm}$ of it was weighed and dissolved in $500 \mathrm{ml}$ volumetric flask. From it $25 \mathrm{ml}$ of $\mathrm{KH}_{2} \mathrm{PO}_{4}$ into $100 \mathrm{ml}$ of volumetric flask.

- For preparation of $0.2 \mathrm{M} \mathrm{NaOH}, 4.00$ of it was weighed and transferred to $500 \mathrm{ml}$ volumetric flask. 
Preparation of different $\mathrm{pH}$ solutions

\begin{tabular}{|c|c|c|c|}
\hline SI. No. & $\mathbf{p H}$ & $\mathbf{K H}_{\mathbf{2}} \mathbf{P O}_{\mathbf{4}} \mathbf{( m \mathbf { m } )}$ & $\mathbf{N a O H}(\mathbf{m l})$ \\
\hline 1 & 6.4 & 25 & 5.80 \\
\hline 2 & 6.6 & 25 & 8.20 \\
\hline 3 & 6.8 & 25 & 11.20 \\
\hline 4 & 7.0 & 25 & 14.55 \\
\hline 5 & 7.2 & 25 & 17.35 \\
\hline 6 & 7.4 & 25 & 19.55 \\
\hline 7 & 7.6 & 25 & 21.20 \\
\hline 8 & 7.8 & 25 & 22.25 \\
\hline
\end{tabular}

Swelling properties of polymer MR-I (Gelatin + Sodium alginate)

\begin{tabular}{|c|c|c|c|c|}
\hline Sl. No. & $\begin{array}{l}\text { Polymer (MR-I) } \\
\mathrm{pH}\end{array}$ & $\begin{array}{l}\text { Particle size of } \\
\text { polymer before } \\
\text { swelling }(\mathrm{mm})\end{array}$ & $\begin{array}{l}\text { Time taken to } \\
\text { swell (min) }\end{array}$ & $\begin{array}{l}\text { Percentage change in } \\
\text { Particle size } \\
\text { polymer after swelling }\end{array}$ \\
\hline 1 & 6.4 & 10.0 & 1.30 & 50.00 \\
\hline 2 & 6.6 & 10.2 & 1.25 & 68.00 \\
\hline 3 & $\mathbf{6 . 8}$ & $\mathbf{9 . 9}$ & $\mathbf{0 . 2 9}$ & $\mathbf{1 0 5 . 0 0}$ \\
\hline 4 & $\mathbf{7 . 0}$ & $\mathbf{1 0 . 0}$ & $\mathbf{0 . 3 0}$ & $\mathbf{9 8 . 0 0}$ \\
\hline 5 & $\mathbf{7 . 2}$ & $\mathbf{1 0 . 1}$ & $\mathbf{0 . 3 6}$ & $\mathbf{1 0 2 . 0 0}$ \\
\hline 6 & $\mathbf{7 . 4}$ & $\mathbf{1 0 . 0}$ & $\mathbf{0 . 3 2}$ & 75.00 \\
\hline 7 & 7.6 & 9.8 & 1.00 & 64.00 \\
\hline 8 & 7.8 & 10.1 & 1.02 & \\
\hline
\end{tabular}

Swelling properties of polymer MR-II (Sodium alginate + Polyvinyl chloride)

\begin{tabular}{|c|c|c|c|c|}
\hline S1. No. & $\begin{array}{l}\text { Polymer (MR-II) } \\
\mathrm{pH}\end{array}$ & $\begin{array}{l}\text { Particle size of } \\
\text { polymer before } \\
\text { swelling }(\mathrm{mm})\end{array}$ & $\begin{array}{l}\text { Time taken to } \\
\text { swell (min) }\end{array}$ & $\begin{array}{l}\text { Percentage change in } \\
\text { Particle size of } \\
\text { polymer after swelling }\end{array}$ \\
\hline 1 & 6.4 & 9.5 & 1.15 & 45.00 \\
\hline 2 & 6.6 & 9.8 & 1.22 & 55.00 \\
\hline 3 & $\mathbf{6 . 8}$ & $\mathbf{1 0 . 2}$ & $\mathbf{0 . 2 8}$ & $\mathbf{1 0 9 . 0 0}$ \\
\hline 4 & $\mathbf{7 . 0}$ & $\mathbf{1 0 . 0}$ & $\mathbf{0 . 3 1}$ & $\mathbf{9 7 . 0 0}$ \\
\hline 5 & $\mathbf{7 . 2}$ & $\mathbf{1 0 . 0}$ & $\mathbf{0 . 3 3}$ & $\mathbf{9 9 . 0 0}$ \\
\hline 6 & $\mathbf{7 . 4}$ & $\mathbf{1 0 . 1}$ & $\mathbf{0 . 3 4}$ & 65.00 \\
\hline 7 & 7.6 & 9.6 & 1.14 & 76.00 \\
\hline 8 & 7.8 & 10.0 & 1.05 & \\
\hline
\end{tabular}



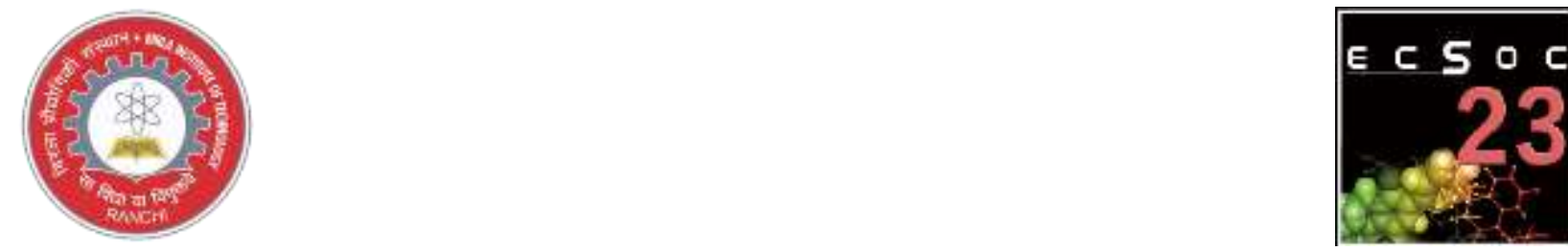

\section{Swelling properties of polymer MR-III (Polyvinyl alcohol + Gelatin)}

\begin{tabular}{|c|c|c|c|c|}
\hline S1. No. & $\begin{array}{l}\text { Polymer (MR-III) } \\
\mathrm{pH}\end{array}$ & $\begin{array}{l}\text { Particle size of } \\
\text { polymer before } \\
\text { swelling }(\mathrm{mm})\end{array}$ & $\begin{array}{l}\text { Time taken to } \\
\text { swell (min) }\end{array}$ & $\begin{array}{l}\text { Percentage change in } \\
\text { Particle size of } \\
\text { polymer after swelling }\end{array}$ \\
\hline 1 & 6.4 & 9.7 & 1.10 & 47.00 \\
\hline 2 & 6.6 & 9.9 & 1.18 & 60.00 \\
\hline 3 & $\mathbf{6 . 8}$ & $\mathbf{1 0 . 0}$ & $\mathbf{0 . 2 9}$ & $\mathbf{1 0 6 . 0 0}$ \\
\hline 4 & $\mathbf{7 . 0}$ & $\mathbf{1 0 . 2}$ & $\mathbf{0 . 3 2}$ & $\mathbf{9 8 . 0 0}$ \\
\hline 5 & $\mathbf{7 . 2}$ & $\mathbf{1 0 . 1}$ & $\mathbf{0 . 3 4}$ & $\mathbf{9 5 . 0 0}$ \\
\hline 6 & $\mathbf{7 . 4}$ & $\mathbf{1 0 . 0}$ & $\mathbf{0 . 3 6}$ & 62.00 \\
\hline 7 & 7.6 & 9.4 & 1.07 & 73.00 \\
\hline 8 & 7.8 & 9.6 & 1.09 & \\
\hline
\end{tabular}

\section{INTERPRETATION:}

1. At $\mathrm{pH} 6.8-7.4$ the swelling of polymer is maximum therefore this mean polymer can deliver the drug at specific $\mathrm{pH}$ site.

2. The polymer may also show property for identification of metastatic cancer cells developing in other parts.

3. Since, the drug is site specific it will show less toxicity and dosage may also get reduced.

4. Side effects of the drug will also decrease due to this target specific property

\section{BIBLIOGRAPHY}

Ahn SH, Koh JH, Seo JA, Kim JH. Structure control of organized mesoporous TiO2 films templated by graft copolymers for dye-sensitized solar cells. Chem Commun. 2010;46(11):1935-

Akashi M, Kirikihira I, Miyauchi N. Synthesis and polymerization of a styryl terminated oligovinylpyrrolidone macromonomer. Die Angew Makromol Chemie. 1985;132(1):81-9.

Bayer E, Dengler M, Hemmasi B. copolymer, synthesis of insulin B21-30. 1985;(7):178-86.

Beyaz K, Charton M, Rouilly A, Vedrenne E, Vaca-Garcia C, Benaboura A, et al. Synthesis of graft-copolymers from palm cellulose and solketal acrylate and their characterization. Ind Crops Prod [Internet]. 2017;97:32-40. Available from: http://dx.doi.org/10.1016/j.indcrop.2016.12.001

Biswal DR, Singh RP. Characterization of carboxymethyl cellulose and polyacrylamide graft copolymer. Carbohydr Polym. 2004;57(4):379-87.

Chauhan GS, Guleria L, Lal H. Synthesis of graft copolymers of acrylamide and comonomers on to cellulose: A study of the effect of comonomer on polymer yields, structure, and properties. Polym Polym Compos. 2003;11(1):19-29.

Chen W, Zou Y, Jia J, Meng F, Cheng R, Deng C, et al. Functional poly(??-caprolactone)s via copolymerization of ??caprolactone and pyridyl disulfide-containing cyclic carbonate: Controlled synthesis and facile access to reduction-sensitive biodegradable graft copolymer micelles. Macromolecules. 2013;46(3):699-707.

Corner T. Free radical polymerization. The synthesis of graft copolymers. Adv Polym Sci. 1984;62:95-142.

Feng C, Li Y, Yang D, Hu J, Zhang X, Huang X. Well-defined graft copolymers: From controlled synthesis to multipurpose applications. Chem Soc Rev. 2011;40(3):1282-95. 

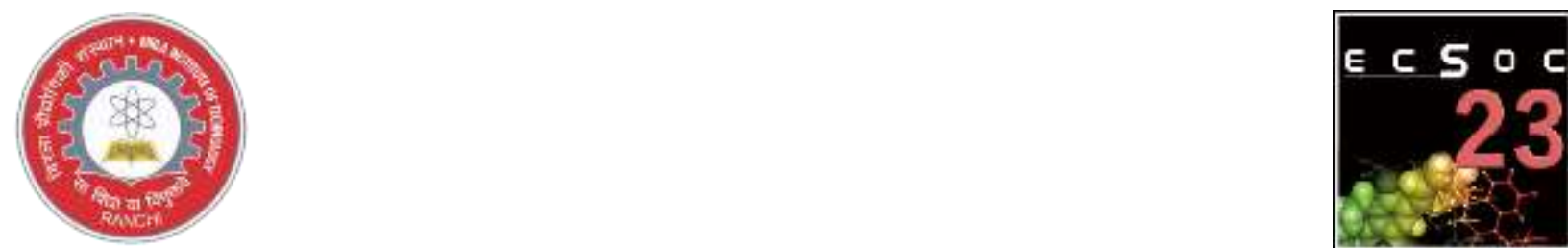

Huacai G, Wan P, Dengke L. Graft copolymerization of chitosan with acrylic acid under microwave irradiation and its water absorbency. Carbohydr Polym. 2006;66(3):372-8.

Jung JP, Park CH, Lee JH, Park JT, Kim JH, Kim JH. Facilitated olefin transport through membranes consisting of partially polarized silver nanoparticles and PEMA-g-PPG graft copolymer. J Memb Sci [Internet]. 2018;548(November 2017):149-56. Available from: https://doi.org/10.1016/j.memsci.2017.11.020

Kim SY, Cho SM, Lee YM, Kim SJ. Thermo- and pH-responsive behaviors of graft copolymer and blend based on chitosan and N-isopropyl acrylamide. J Appl Polym Sci. 2000;78(7):1381-91.

McLean JK, Guillen-Castellanos SA, Parent JS, Whitney RA, Resendes R. Synthesis of graft copolymer derivatives of brominated poly(isobutylene-co-isoprene). Eur Polym J. 2007;43(11):4619-27.

Mishra DK, Tripathy J, Behari K. Synthesis of graft copolymer (k-carrageenan-g-N, N-dimethyl acrylamide) and studies of metal ion uptake, swelling capacity and flocculation properties. Carbohydr Polym. 2008;71(4):524-34.

Moad G. Synthesis of polyolefin graft copolymers by reactive extrusion. Vol. 24, Progress in Polymer Science (Oxford). 1999. 81-142 p.

Mott T, Holland SA. What is a safe dose for chronic daily acetaminophen users? Evidence-Based Pract. 2016;19(12):13-4.

Nayak BR, Singh RP. Development of graft copolymer flocculating agents based on hydroxypropyl guar gum and acrylamide. J Appl Polym Sci. 2001;81(7):1776-85.

Rempp PF, Lutz PJ. 12 - Synthesis of Graft Copolymers. 1989; XXXIV:403-21. Available from; http://www.sciencedirect.com/science/article/pii/B9780080967011001920

Shen D, Yu H, Huang Y. Synthesis of graft copolymer of ethylcellulose through living polymerization and its selfassembly. Cellulose. 2006;13(3):235-44.

Swain S, Bal T. Carrageenan-guar gum microwave irradiated micro-porous interpenetrating polymer network: A system for drug delivery. Int J Polym Mater Polym Biomater [Internet]. 2018;0(0):1-10. Available from: https://doi.org/10.1080/00914037.2018.1443931

Tezuka Y, Fukushima A, Imai K. Synthesis of poly ( viny1 alcohol )/ poly ( dimethylsiloxane ) graft copolymer. 1985;694:685-94.

Thakur VK, Thakur MK, Gupta RK. Graft copolymers from cellulose: Synthesis, characterization, and evaluation. Carbohydr Polym [Internet]. 2013;97(1):18-25. Available from: http://dx.doi.org/10.1016/j.carbpol.2013.04.069

Thakur VK, Thakur MK, Gupta RK. Graft copolymers of natural fibers for green composites. Carbohydr Polym [Internet]. 2014;104(1):87-93. Available from: http://dx.doi.org/10.1016/j.carbpol.2014.01.016

Thakur VK, Thakur MK, Gupta RK. Rapid synthesis of graft copolymers from natural cellulose fibers. Carbohydr Polym [Internet]. 2013;98(1):820-8. Available from: http://dx.doi.org/10.1016/j.carbpol.2013.06.072

Theryo G, Jing F, Pitet LM, Hillmyer MA. Tough polylactide graft copolymers. Macromolecules. 2010;43(18):73947.

Tripathi R, Mishra B. "Development and Evaluation of Sodium Alginate-Polyacrylamide Graft-Co-polymer-Based Stomach Targeted Hydrogels of Famotidine". AAPS PharmSciTech [Internet]. 2012;13(4):1091-102. Available from: http://www.springerlink.com/index/10.1208/s12249-012-9824-1

Tripathy J, Mishra DK, Yadav M, Behari K. Synthesis, characterization and applications of graft copolymer (Chitosang-N, N-dimethyl acrylamide). Carbohydr Polym [Internet]. 2010;79(1):40-. Available from: http://dx.doi.org/10.1016/j.carbpol.2009.07.026

Wu Y, Zheng Y, Yang W, Wang C, Hu J, Fu S. Synthesis and characterization of a novel amphiphilic chitosanpolylactide graft copolymer. Carbohydr Polym. 2005;59(2):165-71.

Yamashita Y, Chujo Y, Kobayashi H, Kawakami Y. Graft Copolymers by Polycondensation Reactions of Macromonomers. 1981;366:361-6.

Zeng D, Chen T, Zhou S. Synthesis of polyaspartic acid/chitosan graft copolymer and evaluation of its scale inhibition and corrosion inhibition performance. Int J Electrochem Sci [Internet]. 2015;10(11):9513-27. Available from: http://dx.doi.org/10.1016/j.desal.2012.11.026

Zhao B, Hu H, Haddon RC. Synthesis and properties of a water-soluble single-walled carbon nanotube-poly $(\mathrm{m}-$ aminobenzene sulfonic acid) graft copolymer. Adv Funct Mater. 2004;14(1):71-6. 